\title{
W STRONE CYFROWEJ DYDAKTYKI AKADEMICKIEJ XXI WIEKU. PRÓBA ROZPOZNANIA
}

\author{
MiROSŁAW WOBALIS
}

\section{Wprowadzenie}

W niniejszym artykule podnosi się kwestię złożoności szeroko ujętego współczesnego środowiska nauczania w zakresie kształcenia humanistycznego obejmującego uwarunkowania technologiczne i przemiany społeczno-kulturowe ${ }^{1}$. Wymienia się dwie sprzeczne postawy wobec technologii i przemian cywilizacyjnych oraz postuluje się przyjęcie trzeciego, realistycznego i pragmatycznego stanowiska. $\mathrm{Hu}-$

\footnotetext{
${ }^{1}$ Wykształcenie humanistyczne, postawę humanistyczną, rolę i miejsce humanisty w społeczeństwie rozumiem tak, jak zdefiniowała je Teresa Kostkiewiczowa w artykule Czy świat potrzebuje humanistów? Jest więc to kształcenie filologiczno-historyczne przygotowujące do realizacji trzech ważnych zadań: a) dbałości o zachowanie i utrwalanie w świadomości zbiorowej przekazu tradycji; b) odpowiedzialności za sferę wartości w obszarze ludzkiego bytowania; c) czuwania nad stanem języka, jako podstawowego narzędzia komunikacji społecznej oraz sposobami jego użytkowania (Kostkiewiczowa, 2014). Szerzej o kształceniu humanistycznym (zwłaszcza w kontekście współczesnych przemian) piszą m.in. P.M. Markowski w książce Polityka wrażliwości. Wprowadzenie do humanistyki (Markowski, 2013), Anna Czubanowska-Wróbel w artykule Czy naprawdę wiemy, gdzie jesteśmy? Uniwersyteckie ksztatcenie humanistyczne w kontekście socjologicznym (Czubanowska-Wróbel, 2014), H.G. Gadamer w tekście Prawda w naukach humanistycznych (Gadamer, 2008). Kompetencje humanistyczne i wężej polonistyczne, szeroko dyskutowane były w trakcie ogólnopolskiego I Kongresu Dydaktyki Polonistycznej w Krakowie w roku 2013 (Polonistyka dziś - ksztatcenie dla jutra, 2014), kompetencje zawodowe przynależne wykształceniu humanistów (w ramach filologii polskiej i z uwzględnieniem wymagań współczesnego rynku pracy) omawiane były w trakcie ogólnopolskiej konferencji Polonista na rynku pracy w roku 2015 w Poznaniu (Polonista na rynku pracy, 2015).
} 
manistyczną edukację akademicką postrzega się szeroko i kontekstowo (w powiązaniu $\mathrm{z}$ etapami poprzedzającymi, kontekstem społecznym, kontekstem technologicznym) $\mathrm{z}$ uwzględnieniem szeregu zagrożeń cywilizacyjnych i demograficznych. Zwraca się uwagę na istotną rolę tego etapu edukacji oraz jego niezagrożone miejsce, jako przestrzeni tworzenia elit nowoczesnego społeczeństwa sieciowego. Zwraca się uwagę, że cyfrowa dydaktyka akademicka nie może istnieć w oderwaniu od tradycji kształcenia, celów formacyjnych społeczeństwa sieciowego i kompetencji XXI wieku oraz głównych nurtów psychologii nauczania: behawioryzmu, konstruktywizmu, kognitywistyki i aktualnych ustaleń neurodydaktyki ${ }^{2}$.

\section{Postawy wobec technologii: optymistyczna, pesymistyczna i pragmatyczna}

Funkcjonujące w przestrzeni społecznej opinie i komentarze dotyczące współczesnych zmian i tendencji cywilizacyjnych (wiązanych z szeroko pojętymi zjawiskami tworzenia się społeczeństwa informacyjnego, lub sieciowego, lub opartego na wiedzy) pozwalają na wyodrębnienie dwóch postaw, które prezentują odmienne podejście do technologii, nowych mediów, nauczania, wychowania, szkoły a nawet - idąc najdalej, do przyszłości cywilizacji technologicznej.

Jedna $\mathrm{z}$ tych postaw charakteryzuje się szeroko pojętym optymizmem. To przestrzeń entuzjasty nowoczesności, miłośnika dynamiki i wszelkich nowinek technologicznych. Entuzjasta charakteryzuje się zachwytem nad zmianami cywilizacyjnymi (dzięki którym np. nasza egzystencja staje się coraz dłuższa, a nowoczesna medycyna znacznie lepiej radzi sobie z coraz liczniejszą grupą chorób), nowymi możliwościami jakie daje technologia informatyczna (natychmiastowa komunikacja i niegraniczony dostęp do informacji), nowymi sposobami życia codziennego (dzięki, któremu nasze ciała i umysły są znacznie dłużej sprawne). Dla entuzjasty nasze

\footnotetext{
${ }^{2}$ Zagadnienie kompetencji związanych ze współczesnymi oczekiwaniami wobec człowieka, definiowanymi przede wszystkim uwarunkowaniami społecznymi i rynkowymi, jest w ostatnim czasie bardzo często poddawane redefiniowaniu i modernizowaniu w zależności od przyjętej perspektywy i oczekiwań. Określenie „kompetencje XXI wieku” pochodzi z wydanej w ramach OECD międzynarodowej publikacji Istota uczenia się. Wykorzystanie wyników badań w praktyce z roku 2013 (Istota uczenia się, 2013). Ta z kolei publikacja szeroko korzysta z ustaleń amerykańskich stowarzyszeń edukacyjnych (m.in. Partnership for 21st Century Skills, 2004, NCREL 21st Century Skills: Literacy In the Digital Age, 2003). W oficjalnym dokumencie programowym Unii Europejskiej pt. Kompetencje kluczowe w procesie uczenia się przez całe życie (będącym jednocześnie zaleceniem dla wszystkich krajów członkowskich UE) korzysta się z pojęcia „kompetencji kluczowych dla rozwoju człowieka” (UE, 2007). W polskiej literaturze programowej związanej z nauczaniem (podstawy programowe wraz z komentarzami) warto zwrócić uwagę na działania Macieja M. Sysło, który propaguje (i dostosowuje do warunków polskich) zarówno koncepcje amerykańskie jak i europejskie [online], http://www.informatykaplus. edu.pl/infp.php/syslo.html [dostęp: 30.01.2017].
} 
bezpośrednie otoczenie staje się coraz bardziej przyjazne (bo technologia gwarantuje bezpieczeństwo), czyste (jeszcze nigdy tak wiele nie mówiło się o ekologii) i dostępne (bilet lotniczy można zarezerwować w minutę, tanie linie dostępne są dla każdego, świat otwarty jest dla turystów). Technologia jest w tej wizji przyjacielem człowieka i codziennym (czasami intymnym) jego towarzyszem. Mówimy tutaj o dziesiątkach urządzeń, dzięki którym śpimy i budzimy się, jemy, pracujemy, podróżujemy, komunikujemy się, uczymy. Technologie diagnozują choroby, przechowują i pomnażają nasze oszczędności, ułatwiają zakupy i realizację spraw urzędowych, bawią, wzruszają, mogą sprawdzić poziom smogu w naszej okolicy, zamówić taksówkę a nawet umówić na szybką randkę. Wystarczy tani smartfon, połączenie z internetem, konto na „Facebooku” oraz „Google+”, by szybko i „od razu” (efekt kultury ,instant”) mieć dostęp „,do wszystkiego” (efekt konwergencji mediów cyfrowych) $i$,wszędzie" (efekt globalizacji). Technologie cyfrowe oferują odbiorcom dokładnie to, czego oni sobie życzą, bowiem, jak mawiają specjaliści w tej dziedzinie, nowe media stały się dzisiaj „,spersonalizowane"4. Co więcej, już niedługo dzięki rozwojowi sztucznej inteligencji, technologie „pozycjonowanie konsumenta” oraz „kreowania popytu” będą coraz bardziej efektywne ${ }^{5}$. Odpowiedni algorytm, na pod-

\footnotetext{
${ }^{3}$ Na pierwszym spotkaniu ze studentami, w trakcie prowadzonych przeze mnie od roku 2012 zatytułowanych „Laboratorium mediów” (2 rok, drugiego stopnia studiów, na kierunku „Media interaktywne i widowiska" na Wydziale Filologii Polskiej i Klasycznej UAM), wyjaśniam, że nasze zajęcia nie odbywają się w pracowni komputerowej gdyż wszyscy znajdujący się w sali mają przy sobie komputerowe urządzenie multimedialne (laptop lub smartfon), dzięki któremu można profesjonalnie tworzyć, edytować i publikować cyfrowe komunikaty. Nie zdarzyło się do tej pory, by któryś ze studentów nie zgodził się z tym oczywistym faktem - co więcej zdecydowana większość z ulgą przyjmuje informację, że praca odbywać się będzie na ich własnych urządzeniach. Odwołując się do porządków komunikacyjnych Stanisława Puppla studenci ci to w pełni świadomi komunikatorzy hybrydowi (Puppel, 2008).

${ }^{4}$ Tak zwane profilowanie odbiorcy na podstawie analizy wyników wyszukiwania w popularnych wyszukiwarkach, analiza odwiedzanych stron, analiza czasu spędzanego $\mathrm{w}$ określonych serwisach to najbardziej „niewinne” metody analizy użytkownika sieci. W roku 2015 wielki rozgłos zdobył film wideo prezentujący twórcę serwisu Facebook, korzystającego z laptopa z zasłoniętą wbudowaną kamerą internetową (nowoczesne komputery posiadają już funkcję mechanicznego zasłaniania takiej kamery). Specjaliści zajmujący się bezpieczeństwem w sieci z uporem godnym Don Kichota ostrzegają przed wbudowanymi kamerami (przez które można swobodnie podglądać zarówno użytkownika komputera jak i jego mieszkanie), mikrofonami (dzisiaj nie trzeba zakładać podsłuchu - wystarczy włamać się do urządzenia posiadającego mikrofon), lokalizatorami GPS (sprawdzającymi aktualne miejsce pobytu użytkownika).

${ }^{5}$ Krytycy technologii całkowicie słusznie widzą tu dwa ważne aspekty: wszechobecną komercjalizację wraz z powszechną inwigilacją, użytkownik technologii jest w tej wizji celem („target”) działań komercyjnych czyniących z niego wyłącznie konsumenta. Nieprzypadkowo bardzo wiele urządzeń w dzisiejszych czasach jest rozdawanych za darmo lub oferowanych za bardzo niską cenę - wszystko po to, by „pozyskać” kolejnego użytkownika, czyli potencjalnego konsumenta. Warto zwrócić uwagę, że nie wszystkie grupy potencjalnych użytkowników wykazują podobne zainteresowanie sprzedawców dóbr, interesujące są bowiem wyłącznie te, które w przewidywalnej perspektywie czasowej zagwarantują zwrot poniesionych nakładów oraz oczekiwane zyski.
} 
stawie danych pochodzących ze śladów internetowych użytkownika komputera lub urządzenia mobilnego, wykorzystujący olbrzymie bazy danych dotyczących statystyki zachowań użytkowników w sieci, posiłkując się milionami istniejących profili zakupowych internautów, zaproponują osobie marzącej o wyprawie w Himalaje zakup ciepłych butów, czekanów, haków, taniego biletu do Nepalu wraz z mapą gratis ${ }^{6}$. Wysiłek intelektualny związany z pozyskiwaniem przez odbiorcę informacji (lub rozrywki) stanie się w tej wizji zbędny, choć oczywiście nie będzie zabroniony. Technologia będzie zdolna już bowiem „myśleć” za odbiorcę i już dzisiaj chętnie się tymi umiejętnościami chwali ${ }^{7}$. Relacja $\mathrm{z}$ technologiami i oferowanymi przez nie dobrami w coraz większym stopniu staje się przyjazna, by nie powiedzieć radosna i bezgranicznie wciągająca. W takiej wizji kultury, jako technologicznej pan-encyklopedii, po wpisaniu do popularnej wyszukiwarki internetowej hasła „Dylan” znajdziemy listę zawierającą, w pierwszej kolejności, liczne strony odwołujące się do znanego pieśniarza, poety i noblisty, w drugiej kolejności znajdziemy sporo stron nawiązujących do znanego aktora młodego pokolenia zaś na dalszych pozycjach odnajdziemy kilka skromnych stron, dotyczących genialnego walijskiego poety, który do tego stopnia zainspirował tego pierwszego na liście wyszukiwań, że ten sam stał się Dylanem.

Dla nauczyciela, będącego entuzjastą nowoczesności, w optymistycznej wizji współczesności technologia jest jego sprzymierzeńcem w nauczaniu (automatyzuje czynności, umożliwia korzystanie z multimedialności) oraz w samorozwoju (umożliwia dostęp do internetowych baz, publikacji, szkoleń, materiałów dydaktycznych). Technologia jest także sprzymierzeńcem (by nie powiedzieć przyjacielem) ucznia, który w szkole wykorzysta nowoczesne urządzenia do nauki, a w domu do samorozwoju - obie te czynności będą zaś tak ,naturalne” i ,przyjemne”, że nauka stanie się zabawą ${ }^{8}$. Dzięki technologii nauczyciel może „miło” i „przyjemnie” stworzyć materiały dydaktyczne na lekcje lub zajęcia, uczeń dzięki technologii może w „przyjaznej” i „miłej” atmosferze uczyć się czego chce i kiedy chce (lub z informacji zamieszczonej na profilu swojej grupy na tzw. „fejsie” poznać tematy egzaminacyj-

\footnotetext{
${ }^{6}$ To oczywiście przykład niezwykle prostego „pozycjonowania” konsumenta i „kreowania” jego przyszłych potrzeb: wystarczy prześledzić wyszukiwane strony (w tym przypadku związane z podróżami w góry) oraz przeanalizować dokonywane w ostatnim czasie zakupy (np. książki o górach, mapy, wycieczki itd.).

${ }^{7}$ Zapamiętując nasze hasła, podpowiadając poprawienie błędów, automatycznie tłumacząc cyfrowe media na języki obce, sugerując zakupy ulubionych przez nas produktów w najniższych cenach, oferując wycieczki w ulubione przez nas miejsca itd.

${ }^{8}$ Moda na „rozdawanie” uczniom różnorodnych urządzeń mobilnych ma wymiar ogólnoświatowy i nie dotyczy tylko najbogatszych państw. Podobny pomysł pojawił się również kilka lat temu w naszym kraju. Por. Manfred Spitzer Dla każdego ucznia po laptopie (Spitzer, 2013: 65-68). Warto zauważyć, że w dużej grupie informacji marketingowych dotyczących technologii cyfrowych używa się określeń związanych z przyjemnością, zabawą i komfortem - tak jakby praca już nigdy nie miałaby być ciężka, żmudna i męcząca.
} 
ne) $)^{9}$. Postawa technologicznego entuzjazmu rodzi niechęć do tradycyjnej wiedzy, niechęć do tradycyjnych koncepcji nauczania i, co w tym kontekście oczywiste, niechęć do celowej, zinstytucjonalizowanej szkoły powszechnej oraz państwowej uczelni wyższej. Entuzjaści mogą zapytać: skoro wszystko jest w „Google” i w „Wikipedii” to po co się jeszcze uczyć w szkole/na uniwersytecie ${ }^{10}$ ?

Symbolicznymi i wciąż żywotnymi reprezentantami tego spojrzenia są dwa wizjonerskie teksty, których odbicia znajdziemy w większości głosów prezentowanych przez entuzjastów: As we may think Vannevara Busha (Bush, 1945) oraz From computer lib/dream machines Teda Nelsona (Nelson, 1974). Pierwszy z tekstów zawierał wizję Sieci jako nieograniczonej encyklopedii, dzięki której ludzkość stanie się lepsza i szczęśliwsza, drugi przedstawiał wizję hipertekstu (i jego wiele odmian jak hipergramy, hipermapy, rozgałęziające się filmy itd.) jako nowatorskiego modelu komunikacji, który usprawni dotychczasowe sposoby komunikowania się oraz relacje między ludźmi. Warto dodać, że liczną grupę entuzjastycznych wizji (bliskich zaprezentowanych powyżej) zebrali w roku 2012 Anderson i Rainie w badaniu Przysztość internetu przeprowadzonym przez Pew Research Center w Waszyngtonie wśród tysiąca dwudziestu jeden ekspertów od internetu z całego świata (Anderson i Rainie, 2012: 2-3).

Druga $\mathrm{z}$ typowych postaw wobec cyfrowych mediów cechuje się pesymizmem i czarnowidztwem. Symbolicznymi tekstami dla tego nurtu są wydane jeszcze w roku 1932 (lecz promieniujące przez dziesięciolecia) Brave new world Aldousa Huxleya (Huxley, 1932) oraz Technopoly. The surrender of culture to technology Neila Postmana z roku 1993 (Postman, 1993) ${ }^{11}$. W pierwszej z wymienionych pozycji wiedza, nauka oraz technologia służą zniewoleniu społeczeństwa masowego w celu stworzenia nowego porządku świata premiującego wspólność, identyczność i stabilność w odróżnieniu od przestarzałego chaosu miłości i cierpienia, piękna i brzydoty oraz indywidualizmu. W drugiej z książek (a warto dodać, że Postman nie ukrywał swojej fascynacji powieścią Huxleya) definiuje się społeczeństwo, jako miejsce w którym najważniejszym, o ile nie jedynym, celem ludzkiej pracy i myśli jest wydajność, gdzie standardowe procedury, wyliczenia, testy oraz oparte na technologii mierniki statystyczne są pod każdym względem lepsze od oceny ludzkiej.

\footnotetext{
${ }^{9} \mathrm{Na}$ jednej z konferencji poświęconych nowym technologiom w nauczaniu prelegentka „entuzjastka” zaprezentowała wizję możliwości obejrzenia przez studentów wykładu on-line „nawet w kapciach" co, nie ukrywam, wcale się mi (jako nauczycielowi akademickiemu) nie wydało inspirujące.

${ }^{10}$ Niektórzy z entuzjastów zadają takie pytania i bardzo często sami znajdują odpowiedzi polegające na tworzeniu nowych modeli kształcenia. Chcąc jednak uniknąc wchodzenia w dyskurs dotyczący czarnej lub świetlanej przyszłości edukacji (lub post-edukacji) świadomie nie podaję źródeł opisanych w tej części postaw. Są one jednak dość łatwe do odnalezienia w... Google. Szczególnie wartym „polecenia” w tym kontekście jest np. „konektywizm”.

${ }^{11}$ Warto w tym miejscu wspomnieć też o innej ważnej w tym kontekście książce Postmana The end of education. Redefining the value of school (Postman, 1995).
} 
W tak postrzeganym świecie to, czego nie można zmierzyć lub zweryfikować albo nie istnieje, albo nie ma wartości. Obie z zaprezentowanych propozycji niezwykle silnie wpłynęły na pesymistyczne postrzeganie rozwoju współczesnych społeczeństw postkapitalistycznych, stały się także inspiracją dla wielu innych autorów w tym licznych reprezentacji pop-kulturowych.

W pesymistycznej wizji przemian, których jesteśmy świadkami i bezwolnymi uczestnikami, cywilizacja właśnie upada pod ciężarem konsumpcjonizmu (premiującego wyłącznie produkt oraz konsumenta), globalizacji (zacierającej różnice między kulturami), popkultury (premiującej kulturę niską kosztem wysokiej) i liberalizmu światopoglądowego (niszczącego tradycyjne wartości). Wszystkie te niepokojące zjawiska mają jeden wspólny mianownik: jest nim technologia i media masowe, które od czasu oszałamiającej kariery radia wykorzystują zdobycze psychologii i socjologii, by manipulować, ogłupiać, a w efekcie degenerować tak jednostki jak całe społeczności. U podstaw obu leży źle wykorzystywana nauka, która tworzy rozwiązania daleko wykraczające poza naturalne potrzeby człowieka (biotechnologia, nanotechnologia, neuroinżynieria, sztuczna inteligencja). Ważnymi cechami nowych, cyfrowych i globalnych mediów są immersja, fragmentaryczność, konwergencja i iluzja partycypacji (Manovich, 2001; Jenkins, 2007). Ta pierwsza oferuje obezwładniającą zmysłowość i namacalną realność sztucznej rzeczywistości, która angażuje współczesnego użytkownika mediów cyfrowych w stopniu głębszym niż rzeczywistość aż do zatracenia w uzależnieniu ${ }^{12}$. Druga z cech sprawia, że nowe media cyfrowe skupiają się na prezentowaniu wybranych i wyselekcjonowanych (pod względem użytkowym lub komercyjnym) fragmentów rzeczywistości utrudniając lub nawet uniemożliwiając budowanie spójnych całości. Trzecia wykorzystuje wynalazek hipertekstu do tworzenia iluzji obecności użytkownika w przebogatej sieci informacji gwarantującej dostęp do wszystkiego (pan-encyklopedyzm) zaś czwarta (będąca produktem kultury Web2.0) tworzy iluzję bycia czynnym podmiotem i twórcą internetu nie zaś biernym odbiorcą i odtwórcą przekazu medialnego.

Ratunkiem przed tym nowym, wspaniałym cyfrowym światem miałby być powrót do dawnych wartości, powrót do korzeni choćby miało to oznaczać ujednolicanie poglądów, rezygnację z wolności (uznawanej za fałszywą), eliminację treści szkodliwych i powrót do cenzury. Pęd rozwoju należy zahamować a technologię okiełznać. W kontekście nauczania oznaczać to ma różnorodne „powroty”: powrót do dawnego systemu nauczania, powrót do jednego scentralizowanego programu nauczania, jednego podręcznika, jednego i w jak największym stopniu instytucjonalnego modelu kształcenia.

\footnotetext{
${ }^{12}$ Zagadnieniu „cyfrowej demencji” (określenie sformułowane przez koreńskich psychiatrów dla opisania pacjentów ciężko uzależnionych od mediów cyfrowych) i wpływowi mediów cyfrowych na funkcjonowanie mózgu poświęcone są m.in. dwie głośne książki Martina Spitzera (Spitzer, 2013; 2015) oraz Nicholasa Carra (Carr, 2007).
} 
Do obu wizji mam stosunek krytyczny, co nie oznacza oczywiście, że przedstawiciele obu postaw, przynajmniej w części swoich stanowisk, nie mają racji. We wspomnianym wyżej amerykańskim badaniu Przyszłość Internetu (Anderson i Rainie, 2012: 2-3) opinie badanych specjalistów na temat wpływu mediów cyfrowych na rzeczywistość rozkładały się prawie równo po połowie: $55 \%$ badanych stanowili entuzjaści, $42 \%$ pesymiści zaś reszta nie potrafiła jednoznacznie określić swojego stosunku ${ }^{13}$. Moje spojrzenie na przyszłości technologii sytuuje się gdzieś pośrodku obu przedstawionych powyżej (chętnie nazwałbym je „złotym środkiem” choć prawdę mówiąc nie wiem, gdzie tenże środek tak naprawdę umieścić). Wizje optymistów są niezwykle kuszące (nawiązanie do „Fausta” Goethego przyszło w tym miejscu zupełnie nieprzypadkowo), co rodzi we mnie naturalną nieufność i skłania ku wizjom pesymistycznym. Pobieżny nawet przegląd tematów badawczych, którymi zajmuje się współczesna nauka, zapiera dech w piersi (od możliwości konstruowania nanorobotów naprawiających organizm na poziomie komórkowym do cyfrowej telepatii). Lęk budzi jednak śledzenie wiadomości ze świata, w których przedstawia się nowoczesne technologie wykorzystywane do niszczenia planety, do eliminacji ludzi i manipulowania społeczeństwami. Zdaję sobie jednak równocześnie sprawę z tego, że przyjęcie jednej z postaw nie ma żadnego znaczenie dla przyszłości, gdyż TA rewolucja cywilizacyjna już się dokonała, zmiany (również na poziomie neuronalnym) właśnie się utrwalają (o ile w nowych pokolenia cyfrowych dzieci już się nie utrwaliły) i są dla pokolenia „cyfrowych tubylców” nieodwracalne (Carr, 2007; Spitzer, 2013). Niezależnie od pragnień buntu pokolenia „,yfrowych imigrantów" (Prensky, 2001) odejdą w ciszy i z książką w ręku, a żadna nowa rewolucja ludystów, postawa offline lub palenie komputerów nic nie dadzą. Nie ma się także co łudzić, że obserwowane zmiany spadły na nas, pokolenia „ciszy, skupienia i narracji” jak grom z jasnego nieba. Ta zmiana rozpoczęła się i stała się nieodwracalna wraz z wynalezieniem pisma, nabrała dynamiki dzięki wynalazkowi maszyny drukarskiej a nabrała wymiaru globalnego wraz z upowszechnieniem się komputerów i internetu ${ }^{14}$. Nie wiemy jak te zmiany potoczą się dalej, jak będzie

${ }^{13}$ Nieco inaczej przedstawia się analiza postaw wobec przyszłości rozwoju technologii i ich wpływu na ludzi w prowadzonych przeze mnie od roku 2010 badaniach w grupie 677 studentów filologii polskiej. W roku 2016 w grupie badanych studentów $20 \%$ stanowili optymiści, $30 \%$ pesymiści zaś $50 \%$ nie mogło jednoznacznie określić swojego stosunku. Co warte odnotowania w roku 2010 liczba pesymistów i optymistów była prawie równa zaś liczba ocen neutralnych najwyższa ze wszystkich badanych lat. Oznacza to, że wraz ze zwiększaniem się ekspansji nowych mediów zwiększa się subiektywna ocena ich negatywnego wpływu na ludzi (Wobalis, 2016: 120).

${ }^{14} \mathrm{~W}$ tym kontekście warto poczynić jeszcze jedną uwagę o wymiarze dość zasadniczym: rzeczywistość polskiej rewolucji technologicznej, polskich mediów i nowych mediów oraz profil polskich cyfrowych tubylców tylko w ograniczonym stopniu przystają do rzeczywistości krajów Europy Zachodniej a zwłaszcza USA. Media masowe i multimedia znane są tam od dziesiątków lat (a przynajmniej miały tam miejsce dwie ogólnospołeczne fale masowych mediów - radia w latach 30-stych i telewizji w latach 60-tych) a internet pod różnymi postaciami istnieje od lat 80-tych. Mitem zatem jest mówienie w Polsce 
wyglądało życie jednostek i życie społeczeństw za lat 25, 50, 100. Obserwujemy zmieniającą się rzeczywistość niczym pasażer pędzącego samochodu wpatrzony w przestrzeń z nosem przyklejonym do bocznej szyby. Tak: wiemy, że rzeczywistość pędzi, dziki pęd sprawia, że obraz zamazuje się i zlewa, staje się niewyraźny i męczący, nie wiemy w jakim kierunku jedziemy i po co. W dodatku nie możemy przerwać jazdy i wysiąść. W wypowiedziach technologicznych entuzjastów jak i technologicznych pesymistów odnaleźć można podobne zagubienie, niepewność i powracające pytania dotyczące przyszłości. Czy świat stanie się jeszcze bardziej wirtualnie-nierealny? Czy sztuczna inteligencja zastąpi ludzką? Czy roboty powszechnie zastąpią ludzi? Odpowiedzi na te pytania, jak śpiewał wspomniany wcześniej Bob Dylan „zna wiatr”, odnajdzie je jednak i zrobi z nimi użytek pokolenie „cyfrowych tubylców”.

\section{W poszukiwaniu miejsca edukacji}

Próbując, w tej dość niespójnej wizji świata, dostrzec przyszłość edukacji instytucjonalnej (szkoły powszechnej oraz szkolnictwa wyższego) związanej z wykształceniem humanistycznym przede wszystkim nie przyjmuję wizji radykalnych, wieszczących koniec tradycyjnej szkoły (patrz: Neil Postman, The end of education. Redefining the value of school, 1995) takich m.in. jak ta zeprezentowana przez Jana Hartmana:

„Mam nadzieję, że ciągu tego stulecia obowiązkowe szkoły powszechne znikną. Szkoły staną się dobrowolne i zmienią się $\mathrm{w}$ instytucje samo uczenia się pod kierunkiem nauczycieli pomagających dobierać odpowiednie środki i materiały tym, którzy uczyć się pragną i mają po temu jakieś predyspozycje (a z pewnością nie jest to większość ludzi)"15.

Co więcej mam głębokie przekonanie, że akurat nauczanie w takiej formie jaką my sami znamy najlepiej (tj. celowej, instytucjonalnej, w jakiejś formie opresyjnej i skoszarowanej) nie ulegnie w ciągu najbliższych dziesięcioleci żadnym istotnym zmianom. Dotyczyć to będzie zarówno kształcenia powszechnego, zawodowego jak

\footnotetext{
o społeczeństwie informacyjnym, sieciowym oraz opartym na wiedzy w kategoriach dokonanych. Powszechny dostęp do Facebooka nie stworzy społeczeństwa sieciowego, powszechne posiadanie smartfonów nie uczyni z Polaków społeczeństwa informacyjnego a zamontowane w niektórych szkołach i uczelniach tablice multimedialne nie przyczyniają się w żaden sposób do stworzenia społeczeństwa opartego na wiedzy.

${ }^{15} \mathrm{Nie}$ ukrywam jednak, że rozumiem i podzielam zaniepokojenie autora - rozwiązanie widzę jednak nie w wymyśleniu edukacji na nowo ale w jej głębokim przemyśleniu od nowa. J. Hartman, „Umarła klasa”, Magazyn Gazety Wyborczej, 11.05.2013.
} 
i akademickiego ${ }^{16}$. Nie zmieni się gdyż taki model edukacji jest właśnie w dzisiejszych czasach paradoksalnie najbardziej potrzebny - stanowi bowiem jedną z kilku (wraz z kulturą wysoką, dobrym wychowaniem, tradycyjnym normom społecznym i wartościami humanistycznymi) ważną przeciwwagę dla świata opisanego w wizjach pesymistów, ważną kotwicą gwarantującą nam kontakt z przeszłością, bez której ani teraźniejszość, ani przyszłość nie mają racji bytu. Jak słusznie zauważa Hannah Arendt, w odniesieniu do współczesności:

„problem edukacji [...] polega na tym, że w z samej swojej natury nie może ona wyrzec się ani autorytetu, ani tradycji, ale musi przebiegać w świecie, którego struktury nie wyznacza już autorytet i nie spaja tradycja" (Arendt, 1994: 231).

Jeśli świat nowych mediów jest rozedrganą mgławicą wirtualnych pseudobytów, siecią lub labiryntem prowadzącym świadomie lub nieświadomie na manowce, nadmiarem wszystkich zmysłów (przesytem agresywnych barw, dźwięków i interakcji) to szkoły i uniwersytety, ze szczególnym uwzględnieniem przedmiotów szkolnych oraz kierunków akademickich związanych z kształceniem humanistycznym, powinny stanowić dla zmęczonych cyber-wędrowców oazą skupienia, koncentracji, refleksji, selekcji i żmudnej analizy ${ }^{17}$. W realiach bardzo dynamicznych procesów cywilizacyjnych istotną cechą rzeczywistości jest nieustająca i coraz szybsza zmiana, która sprawia, że zmienia się technologia, zmieniają się media, relacje, kultura, edukacja, systemy polityczne oraz oczywiście struktura przemysłu i hierarchia pożądanych przez pracodawców kompetencji zawodowych. Zmiany odbywają się

${ }^{16} \mathrm{O}$ współczesnym kształceniu akademickim Polsce, jego przemianom oraz najbardziej prawdopodobnym kierunkom zmian wyczerpująco pisze Marek Kwiek w swojej książce Uniwersytet $w$ dobie przemian (Kwiek, 2016).

17 „Ów nadmiar informacji obrazowych - wydaje się, że przede wszystkim chodzi właśnie o nadmiar umożliwiony przez technologię - rodzi poczucie obojętności, z której wyrwać może tylko jeszcze silniejszy bodziec: w nowych mediach skorelowany z innymi doświadczeniami percepcji: audialnością czy taktylnością.” „Kultura słyszenia, o której, o której mówi się coraz częściej w odniesieniu do zjawisk nowych mediów, przejawia się poprzez charakterystyczną dla niej audytywność doświadczeń, które nakładają się na siebie, krzyżują, kontaminują itp. Zjawisku temu towarzyszy charakterystyczny nadmiar i wszechobecność dźwięków (oraz innych bodźców zmysłowych, którymi atakuje kultura nowych mediów), czego efektem jest utrata uroczystego charakteru wydarzenia kulturowego na rzecz codziennego doświadczenia, nieauratycznego (...), bezceremonialnego, mieszającego to, co przypadkowe, z celowością przekazu. Co więcej, wszechobecność bodźców we współczesnej kulturze staje się problemem za sprawą emitujących ją mobilnych urządzeń. Można mówić wręcz o dokonywaniu swoistego gwałtu na ludzkich zmysłach. Ucho, wystawione na działania zewnętrznych bodźców, na ataki, wydaje się wręcz bezbronne. Otaczające i sączące się zewsząd akustyczne fajerwerki, wizualne podniety, bodźce zapachowe itp. Prowadzą do kulturowej < głuchoty> lub przynajmniej do stępienia wrażliwości. Nadmiar bodźców powoduje, że współczesny odbiorca <nie słyszy> już konkretnego przekazu, wszystko co go otacza, tworzy bowiem rodzaj szumu wypełniającego środowisko życia człowieka". Oba cytaty Edukacja w czasach cyfrowej zarazy, 2015: 118-120. 
tak szybko, że wiedza nabyta w szkole lub na uczelni niejednokrotnie jest już przestarzała i niewystarczająca, gdy uczniowie i studenci wkraczają w dorosłe życie zawodowe. W coraz większym stopniu dla sukcesu życiowego jednostki ważna nie jest raz nabyta wiedza, ale „umiejętność uczenia się przez całe życie” (Nauczanie $i$ Uczenie się. Na drodze do uczącego się spoteczeństwa. Biała Księga Komisji Europejskiej, 1997) - zdolność zmiany osobistej podążającej za zmianą globalną ${ }^{18}$. Współczesna społeczność nie może być wyłącznie postkapitalistycznym ,,społeczeństwem opartym na wiedzy" (Toffler, 1997), a w coraz większym stopniu musi się stawać społecznością uczącą się i zdolną do szybkiego, samodzielnego przyswajania nowej wiedzy i nowych kompetencji. W tym kontekście istnienie stabilnych i trwałych instytucji edukacyjnych (systemów edukacyjnych) ma znaczenie fundamentalne zaś pojawiające się w tych systemach niedopasowania, błędy lub zapóźnienia skłaniają raczej do korekty niż burzenia. Nie burzy się przecież domu, gdy przecieka dach.

W tym skomplikowanym cywilizacyjnie obrazie, w kontekście miejsca i zadań uniwersytetu w realiach społeczeństwa informacyjnego, uwidoczniły się dwie istotne kwestie - a jednocześnie zadania dla uniwersytetu. Po pierwsze jest to opisane wyżej społeczne miejsce kształcenia instytucjonalnego jako przeciwwagi do „szalejących technologii” i dynamicznych zmian społeczno-gospodarczych i umiejscowienie uniwersytetu w roli instytucji korygującej, stabilizującej i normalizującej. Po drugie istotnym zdaniem jest zachowanie i pieczołowite dbanie o status uniwersytetu jako miejsca, w którym pojmowanie i interpretacja zmian (w tym obraz przeszłości, teraźniejszości i przyszłości) poddawana jest naukowej refleksji i chłodnemu, analitycznemu oglądowi. Nie może się to jednocześnie wiązać z wycofaniem się (zwłaszcza kształcenia humanistycznego) na pozycje elitarnego i zamkniętego skansenu w opozycji do nowoczesnych technologii. Refleksja naukowa w realiach społeczeństwa sieci musi koniecznie być nowoczesna a więc korzystająca z najnowszych technologii informatycznych i możliwości jakie dają nowe media. Nie da się bowiem skutecznie analizować rzeczywistości technologicznej bez technologii tak jak nie da się kształcić nauczycieli dla cyfrowych tubylców bez drobiazgowej dekonstrukcji cyfrowej rzeczywistości i języka nowych mediów.

Rolą uniwersytetu, w kontekście nowych mediów, jest więc stała dbałość o modernizację warsztatu, narzędzi i oferty dydaktycznej zwłaszcza, że dzisiejsi studenci to pokolenia dzieci urodzonych w latach 90-tych, którzy nie znają świata sprzed internetu. Ten fakt otwiera jeszcze jeden ciekawy aspekt związany z technologiami:

\footnotetext{
${ }^{18}$ Technicy lub jak nazywa ich Peterr Drucker „ludzie wiedzy” („knowledge workers”) muszą spełniać określone wymagania, po pierwsze w ich przypadku wykonywanie pracy wymaga przyswojenia sobie konkretnej wiedzy, czyli jest związane z rzetelnym formalnym wykształceniem, po drugie wymaga zdolności do zastosowania nabytej wiedzy i po trzecie wymaga świadomości, że proces uczenia jest procesem ciągłym (Drucker, 2002: 447).
} 
uczniowie i studenci, wychowani z nowymi technologiami sami stają się nośnikami kompetencji cyfrowych. Bardzo często to właśnie od dzieci i młodzieży starsze pokolenia uczą się, jak korzystać z narzędzi nowych technologii. W tym kontekście uniwersytet doskonalący cyfrowe kompetencje przyszłych nauczycieli wpływa na rozprzestrzenianie się tych kompetencji w społecznościach lokalnych - tak może się tworzyć nowa cyfrowa elita. Aby tak się stało przyszli nauczyciele (ale też wydawcy, dziennikarze, tłumacze, animatorzy kultury i inni specjaliści kształceni na kierunkach humanistycznych) powinni opanować kompetencje cyfrowe w takim stopniu, by mógł się stać dla nich dalszego narzędzia doskonalenia się. Ich kompetencje powinny obejmować co najmniej bardzo dobrą wiedzę o specyfice języka nowych mediów i specyfice działania nowoczesnych narzędzi dydaktycznych. Absolwenci powinni także znać dobrze realia społeczne, w których przyjdzie im działać i znać swoją rolę jako lokalnego przekaziciela nowoczesnych kompetencji cyfrowych.

Kolejną istotną umiejętnością absolwenta powinna być umiejętność tworzenia lokalnych społeczności lub ich przekształcania - w kierunku dostosowania się tych społeczności do realiów społeczeństwa obywatelskiego, informacyjnego i sieciowego. Jak słusznie zauważa Andrzej Nowak, autor wprowadzenia do książki Szkoła $w$ dobie Internetu:

„W sumie umożliwienie nauczycielom spełnienia takich oczekiwań wymaga wyjścia poza myślenie w kategoriach szkolenia i przejście do myślenia w kategoriach zmiany społecznej. Zmiany, dzięki której nauczyciel nie tylko zdobędzie nową wiedzę i umiejętności, lecz również nauczy się używać tych kompetencji w pracy z uczniami i w innych swych działaniach. Zmiany, która obejmie nie tylko pojedynczych nauczycieli, ale również szkoły i środowiska lokalne." (Szkoła w dobie Internetu 2009: 9).

Uniwersytet kształcący nowoczesnych humanistów to w końcu miejsce budowania wrażliwości humanistycznej dla społeczeństwa, ale i dla rynku pracy.

„Humanistyczne kształcenie ogólne to właśnie sfera tego rodzaju pytań i postaw, które napędzają ludzką ciekawość i prowadzić mogą doprawdy w najróżniejsze strony, co niekoniecznie odpowiada granicom wyznaczanym przez tradycyjnie pojmowane przedmioty szkolne. Wskazuje za to wiele możliwych przestrzeni i kierunków, które mogą w perspektywie prowadzić także do tak dziś pożądanej specjalizacji. Ogólna edukacja humanistyczna oznacza budowanie świadomości życia w jakimś naturalnym otoczeniu, które w oczywisty sposób jest równocześnie naznaczone kulturowo, i poszukiwania odpowiedzi na pytanie o to, czym się te wzajemnie przenikające elementy otoczenia odznaczają oraz o możliwość refleksji nad tym, jak dalece są one przy-swojone, jak dalece uznaje się je za własne, a jak mogłaby się przeciwstawiać z niewielkiego choćby dystansu. A także, jak się one mają w stosunku do innych kulturowo światów i zamieszkujących je Innych" (Edukacja w czasach cyfrowej zarazy 2015: 139).

Nauka i wykształcenie nadal są potrzebne modne, a przykład krajów znacznie wyżej rozwiniętych jasno pokazuje, że dobrze umocowane społecznie i gospodar- 
czo, dobrze zarządzane kształcenie akademickie jest przez społeczeństwo pożądane, jest niezbędne dla dobrobytu ekonomicznego i innowacji, zaś dla decydentów jest gwarancją rozwoju ich kraju.

Mimo tak silnej ekspansji nowych cyfrowych mediów i wartości społeczeństwa masowego nagroda Nobla wciąż ma znacznie większe znaczenie od nagrody Grammy za najlepszą piosenkę roku.

\section{W poszukiwaniu dydaktyki cyfrowej}

Thomas Edison, wynalazca m.in. żarówki, fonografu i kinematografu, pisał na początku ubiegłego wieku, ,na fali” pierwszej gorączki kina, że:

„Książki w szkołach staną się w najbliższym czasie przestarzałe. Uczniowie będą się uczyć poprzez zmysł wzroku. Dzięki ruchomym obrazom możemy im przekazywać informacje o wszystkich obszarach ludzkiej wiedzy. System szkolnictwa całkowicie zmieni się w przeciągu najbliższego dziesięciolecia” (,The New York Dramatic Mirror”, 1913 July 9$)^{19}$.

Wypowiedź ta jest dla mnie wyjątkowym symbolem stosunku technologicznych entuzjastów do edukacji - a dokładniej do wyznaczania im wyjątkowej roli i miejsca w nauczaniu. Larry Cuban w tekście Teachers and machines: the classroom use of technology since 1920 jednoznacznie wykazał, że wszystkie próby edukacyjnego wdrożenia (lub może nieudolnych prób praktycznego zastosowania) większości najważniejszych dwudziestowiecznych wynalazków i rozwiązań w realiach dydaktycznych zakończyły się mniejszym lub większym fiaskiem (Cuban, 1986). Od wspomnianego kinematografu w latach dwudziestych, poprzez radio od lat trzydziestych i czterdziestych, telewizję edukacyjną w latach pięćdziesiątych, pierwsze komputery i nauczanie programowane z lat sześćdziesiątych i siedemdziesiątych, po wideo i multimedia w latach osiemdziesiątych. Żadna z technologii, choć wszystkie zapowiadano jako rewolucję w nauczaniu, rewolucją się nie stała i przeszła drogę od ciekawej nowinki do zakurzonego starocia. Przyglądając się ekspansji i wpływowi na edukację licznych ,rewolucji technologicznych” XX wieku jasno widać, że edukacja jest na technologię niezwykle oporna (można powiedzieć odporna). W późniejszej pracy (Cuban, 2001) badacz do listy edukacyjnych porażek dołącza najnowsze rozwiązania związane $\mathrm{z}$ technologiami informacyjnymi (zwłaszcza komputery przenośnie i internet), stwierdzając, że

\footnotetext{
${ }^{19}$ Tekst oryginalny: „Books will soon be obsolete in the schools. Scholars will soon be instructed through the eye. It is possible to teach every branch of human knowledge with the motion picture. Our school system will be completely changed in ten years" (tłumaczenie własne- M.W.).
} 
„Każdy cykl rozpoczyna się od wielkich obietnic naukowców i wynalazców nowych technologii. W szkołach akceptacja nowych narzędzi jest raczej niewielka, w związku z czym trudno mówić o prawdziwym postępie naukowym. To z kolei prowadzi często do tych samych spekulacji, w kwestii brakujących środków finansowych, oporu kadry nauczycielskiej albo opieszałości zbiurokratyzowanego systemu szkolnictwa. Jednak nikt nie kwestionuje tego, co wygłaszają prekursorzy nowych technologii, a że obiecywanych efektów postępu wciąż nie widać, ostatecznie odpowiedzialnością za niepowodzenie obarcza się maszyny. Wkrótce potem szkołom sprzedaje się najnowszą generację sprzętu technicznego i tak rozpoczyna się kolejny intratny cykl tego procesu"20.

W podobnym duchu wypowiadał się także Paul Seattler w książce The evolution of american educational technology (Seattler, 1990) również wskazując, że żadna $\mathrm{z}$ nowatorskich technologii (edukacyjne programy telewizyjne, nauczanie za pomocą komputera, interaktywne systemy multimedialne, inteligentne systemy kształcenia indywidualnego), mimo szumnych zapowiedzi, nie zrewolucjonizowała szkoły i nie dokonały przełomu w edukacji.

Mamy więc z jednej strony „niezmordowanych technologicznych optymistów” promujących kształcenie technologiczne zaś z drugiej „zagorzałych pesymistów”, a nawet wrogów technologii w nauczaniu głoszących, że:

„Z wszelkich dostępnych dziś rozpoznań naukowych wynika, że komputer jest potrzebny do nauczania tak samo jak rower do nauki pływania albo aparat rentgenowski do przymierzania butów (...) Komputery nie sprzyjają bowiem kształceniu młodych ludzi, lecz są dla procesu edukacji raczej przeszkodą lub (...) w najlepszym razie nie wywierają na niego żadnego wpływu" (Spitzer, 2013: 25).

Ponownie można stwierdzić, że obie te przeciwstawne postawy, mimo głoszenia z obu stron słusznych argumentów, dalekie są od pragmatycznego „złotego środka”. Bo o ile brak rzetelnych i wiarygodnych dowodów na istotne zwiększanie się efektywności dydaktycznej dzięki technologiom (Cuban, 2001; Mayer, 2005; Spitzer, $2013^{21}$ ) to trudno nie zauważyć, że każda z nowoczesnych technologii wprowadza rozwiązania istotnie wspierające prowadzenie dydaktyki - dzięki obrazowaniu, automatyzacji, tworzeniu, przetwarzaniu i udostępnianiu informacji. W dodatku każda z tych technologii, przez sam fakt obecności w codziennym życiu uczniów i studentów, sama w sobie jest i powinna być przedmiotem edukacyjnego namysłu a ich specyficzny język (nawiązując do Manovicha) powinien być traktowany jako istotny element kompetencji komunikacyjnych człowieka.

\footnotetext{
${ }^{20}$ Cytat za (Spitzer, 2013: 81).

${ }^{21} \mathrm{~W}$ trakcie moich badań nad podręcznikiem multimedialnym języka polskiego do liceum (Wobalis, 2011) wykazałem, że w strategii samodzielnego wykorzystania przez ucznia narzędzia informatycznego w domu spadek efektywności w zakresie symbolicznego odczytania zadanych tekstów kultury wynosi od $30 \%$ do nawet $50 \%$ w porównaniu do pracy z tymi samymi tekstami w szkole wraz z nauczycielem.
} 
Jedynym sensownym i praktycznie uzasadnionym powodem wprowadzania technologii $\mathrm{w}$ obszar nauczania nie jest więc ich hipotetyczna rola narzędzia zwiększającego efektywność dydaktyczną lecz rzeczywista i pragmatyczna rola narzędzia codziennej pracy, nauki i zabawy poza szkoła. Takie postrzeganie technologii całkowicie zmienia dotychczasowy paradygmat bezowocnego stosowania technologii wiążąc ją ściśle ze szkołą i znajduje dla niej zastosowanie bliskie człowiekowi i jego potrzebom. Te zaś związane są z tym, co absolwent robić będzie po zakończeniu nauczania, szczególnie z jego prawdopodobną ścieżką kariery zawodowej.

Biorąc pod uwagę istniejące uwarunkowania cywilizacyjne społeczeństwa informacyjnego istnieje bardzo duże prawdopodobieństwo, że absolwenci kierunków ścisłych, technicznych, przyrodniczych, w ramach swojej ścieżki zawodowej, będą mieli częstszy kontakt z technologiami informatycznymi (związanymi z komputerami) niż absolwenci kierunków humanistycznych, społecznych lub artystycznych. Ci zaś najpewniej znacznie częściej korzystać będą w swojej pracy zawodowej z technologii informacyjnych (związanymi z mediami) niż informatycznych. Nikt nie podważa faktu, że uczniowie profili matematyczno-fizycznych mają częściej zajęcia z matematyki niż uczniowie profili humanistycznych - ci zaś częściej uczą się języka polskiego i historii. Takie podejście do zagadnienia wychodzi od studenta i jego potrzeb, nie zaś od procesu dydaktycznego i jego uwarunkowań wraz z technologią i jej hipotetycznymi możliwościami (lub rzeczywistymi ułomnościami).

\section{Psychologiczne i neurobiologiczne podstawy kształcenia cyfrowego}

Nabywaniu kompetencji, które na wstępie ujęliśmy mianem umiejętności XXI wieku, jak zauważyliśmy wyżej, powinno uwzględniać zarówno obraną ścieżkę zawodową studenta (i wynikające z tego kompetencje zawodowe) oraz odbywać się $\mathrm{w}$ triadzie trzech powiązanych grup kompetencji podstawowych dla wszystkich uczących się: kompetencji komunikacyjnych, językowych oraz informatycznych/informacyjnych (cyfrowych). Projektowanie zajęć powinno także uwzględniać ustalenia psychologii poznawczej (w tym behawioryzmu), konstruktywizmu (w ujęciu Jeana Piageta oraz konstrukcjonizmu w ujęciu George'a Kelly'ego) a zwłaszcza ustaleń neurobiologii i neurodydaktyki (w stopniu zasadniczym). Zaczynając od ostatniej z wymienionych, współczesna neurobiologia dość jednoznacznie potrafi wskazać nie tylko ,jak” i ,kiedy” człowiek się najefektywniej uczy (zapamiętuje informacje i przetwarza je na wiedzę) ale również, co być może jest w przypadku relacji technologii i nauczania istotniejsze, kiedy człowiek się na pewno nie uczy. Wyniki licznych badań neurobiologicznych zebranych i opublikowanych przez Nicholasa Carra (Carr, 2007) a zwłaszcza Manfreda Spitzera (Spitzer, 
2001; 2013; 2015) jasno wskazują, że bezkrytyczne wykorzystywanie narzędzi cyfrowych nie tylko nie poprawia jakości i efektywności kształcenia a może nawet prowadzić do skutków odwrotnych. Nadmiar bodźców zwykle prowadzi nie do zwielokrotnienia przyswajania informacji ale do obniżenia procesu zapamiętywania. Łączone z nowymi mediami wielozadaniowość, wielowątkowość, interaktywność i polisensoryczność prowadzą wyłącznie do rozproszenia uwagi i spadku efektywności zapamiętywania (Spitzer, 2013: 193-203). Kolejnym ważnym elementem jest fakt, że ludzki mózg przystosowany jest do pracy w realnym działaniu (naturalnym a nie wirtualnym środowisku) oraz $\mathrm{w}$ ramach interakcji $\mathrm{z}$ żywymi ludźmi $\mathrm{w}$ tym szczególnie w ramach pracy grupowej. W związku z tym wszelkie próby zastąpienia „żywego” kształcenia kształceniem zdalnym lub kształceniem prowadzonym przez maszyny jest z góry skazane na porażkę. Kolejną istotną kwestią podnoszoną przez neurobiologów jest fakt, że człowiek znacznie efektywniej uczy się poprzez ciężką pracę i realne wyzwania (i realne nagrody) w świecie rzeczywistym niż poprzez zabawę, przyjemność i wirtualne symulacje. Dotyk i realne odczuwanie rzeczywistości przyrody zawsze przewyższy kliknięcie w obrazek i obrócenie wirtualnego drzewa. Dzieje się tak dlatego, że mózg znacznie łatwiej koduje informacje związane $\mathrm{z}$ realnymi emocjami, prawdziwymi wyzwaniami i komunikacją $\mathrm{w}$ ramach pracy w grupie innych uczących się.

Te ustalenia bliskie są założeniom psychologii konstruktywistycznej i kognitywnej, które zwracają uwagę na duże znaczenie samodzielnej/własnej pracy intelektualnej uczącego się, który sam (lub z pomocą nauczyciela - przewodnika) konstruuje własną wiedzę. Im bardziej ta praca zbliżona jest do modelu badawczego, eksperymentalnego i związanego z rozwiązywaniem rzeczywistych problemów zwłaszcza w ramach pracy grupowej tym lepiej. Bardzo interesujące i praktyczne rozwinięcia tych ustaleń, zwłaszcza w obszarze kształcenia kompetencji cyfrowych, zaproponował pod koniec XX wieku Seymour Papert, który jednoznacznie uznawał, że:

„Uczniowie tworzą nowe idee szczególnie skutecznie wtedy, gdy są aktywnie zaangażowane w konstruowanie różnego rodzaju artefaktów - może to być robot, poemat, zamek z piasku, program komputerowy lub cokolwiek innego, czym można się podzielić z innymi i co może być przedmiotem wspólnej analizy i refleksji." (Walat, 2007: 8).

Według tej koncepcji uczeń nie jest wyłącznie odbiorcą ale przede wszystkim jest twórcą (za przedstawicielami konstrukcjonizmu powiedzielibyśmy: konstruktorem) swojej wiedzy. Wychodząc na przeciw rozwojowi społeczeństwa sieciowego, powstaniem nowych cyfrowych kompetencji i próbując stworzyć uniwersalną wykładnię efektywnego kształcenia cyfrowego Papert stworzył w roku 2005 osiem zasad skutecznego uczenia się $\mathrm{w}$ nowej rzeczywistości cywilizacyjnej. Pierwszą wielką ideą jest uczenie się przez tworzenie, druga idea dotyczy technologii jako tworzywa, trzecia idea to idea nauki jako zabawy (w oryginale „ostrej zabawy”- 
„hard fun”). Czwarta to idea uczenia się jak się uczyć, piąta głosi: daj sobie czas odpowiedni do zadania, szóstą ideą (uznaną za najważniejszą ze wszystkich): jest zasada, że nie ma sukcesu bez niepowodzeń, siódma odnosi się do pracy nauczyciela i głosi: praktykuj sam, co zalecasz uczniom. Ósma wielka idea jest podsumowaniem i głosi: wkraczamy w cyfrowy świat, w którym znajomość technologii cyfrowej jest równie ważna, jak czytanie i pisanie. Tak więc uczenie się o komputerach jest kluczowe dla przyszłości naszych uczniów. Ale najważniejszym celem jest używanie ich TERAZ do uczenia się innych przedmiotów (Walat, 2007: 9).

Wiedzę najpełniej przyswaja się dzięki interakcji z rzeczywistym światem otaczającym uczącego się (określanym w literaturze przedmiotu ,środowiskiem uczenia się") co w żaden sposób nie wyklucza a nawet uzasadnia potrzebę wykorzystywania $w$ ramach tego procesu narzędzi technologicznych ${ }^{22}$. O ile rzeczywiście ma to uzasadnienie w realnym życiu - do czytania najlepiej bowiem nadaje się papier i książka a nie ekran komputerowy, do pisania elektronicznego klawiatura nie zaś rysik i tablet zaś do kwerendy bibliotecznej komputer z dostępem do Internetu zamiast przeglądania szufladek z papierowymi fiszkami. Nie potrzebujemy jednak komputera i Excela, by dokonać prostych obliczen - wystarczą nam nabyte w szkole umiejętności, kartka papieru oraz długopis. Istotny jest bowiem kontekst nauczania czyli rzeczywiste ramy środowiska, w jakim uczymy.

$\mathrm{Na}$ fali mody na interaktywne multimedia w latach osiemdziesiątych badacze chętnie podkreślali atrakcyjność polisensoryczności i interaktywności tych mediów. Dane o wysokiej efektywności multimediów ${ }^{23}$ były później wielokrotnie powielane mimo (o czym już wspomnieliśmy wyżej) braku jednoznacznych wyników badań potwierdzających wysoką efektywność dydaktyczną multimediów. Wspomniane wyżej ustalenia badań neurobiologicznych jednoznacznie wskazują, że polisensoryczność i interaktywność multimediów przyczynia się do spadku koncentracji i uwagi uczącego się a tym samym przyczynia się co najmniej do zmniejszenia efektywności dydaktyki prowadzonej poprzez multimedia i interaktywne media cyfrowe - szczególnie silnie angażujące gry i interaktywne zabawy komputerowe. Na identyczne, negatywne skutki ,przemęczenia” umysłu uczącego się bodźcami medialnymi wskazują badacze edukacyjnych mediów interaktywnych (Sweller, 1993; Mayer, 2013) ${ }^{24}$. Z tego też względu, we współczesnych podejściu do dydaktyki

\footnotetext{
${ }^{22}$ Wagę kontekstu środowiskowego w nauczaniu wprowadził Lev Wygotski, przedwcześnie zmarły (w roku 1932) rosyjski psycholog „odkryty” dla współczesnej teorii nauczania przez amerykańskich kognitywistów w latach siedemdziesiątych XX wieku

${ }^{23}$ Zob. Bernard Steinbrink, 1993, Multimedia. U progu XXI wieku, Wrocław, s. 51, Józef Bednarek, 2006, Multimedia w kształceniu, Warszawa, s.16.

${ }^{24}$ Sweller (1993) wprowadził interesujące w tym kontekście pojęcie „przetwarzania zbędnego”, które oznacza niepotrzebne lub zakłócające obciążenie poznawcze w trakcie uczenia się. Zazwyczaj spowodowane jest złym połączeniem materiałów dydaktycznych, złą ich prezentacją. Z tym zjawiskiem bardzo często mamy do czynienia w przypadku multimediów, które właśnie ze względu na swoją polin-
} 
cyfrowej dominuje pogląd, że w kształceniu z wykorzystaniem nowoczesnych narzędzi należy łączyć teorie behawioralne, poznawcze i konstruktywistyczne w pierwszym rzędzie w celu ograniczania negatywnego wpływu mediów cyfrowych na uczących się. Nie oznacza to oczywiście rezygnacji z używania technologii cyfrowych ale takiego ich powiązania z procesem, by po pierwsze nie zakłócać samego procesu nauczania zbędnym i nic nie wnoszącym użyciem narzędzi, oraz po drugie, by opracować metody efektywnego włączania nowych technologii do procesu nauczania.

Amerykański badacz edukacyjnych mediów interaktywnych Richard E. Mayer, opierając się na wynikach badań neurologicznych oraz korzystając z dokonań psychologii poznawczej i kognitywistyki zaproponował pięć zasad eliminowania zbędnego oddziaływania mediów cyfrowych. Są to następujące zasady:

1. Spójności - nakazująca zmniejszanie ilości zbędnego materiału,

2. Sygnalizowania - oznaczająca podkreślanie ważnego materiału

3. Redundancji - sugerująca unikanie dodawania do wyświetlanego na ekranie tekstu do animowanej narracji

4. Sąsiedztwa przestrzennego - nakazującej umieszczanie drukowanego tekstu obok odnośnego materiału graficznego

5. Sąsiedztwa czasowego - podkreślającej wagę jednoczesności prezentowania narracji wraz ze stosowną animacją.

Te proste zasady odnoszą się do typowych metod prezentowania materiału dydaktycznego, obecnego na każdym etapie kształcenia, z akademickim włącznie. Dotyczą takich technik jak prezentacje Power Point (lub inne tego typu), podręczniki elektroniczne (m.in. w rodzaju plików PDF), komputerowe programy multimedialne, platformy e-learningowe. Są uniwersalne i w skrócie można je sprowadzić do następujących generalnych zaleceń: mniej zamiast więcej, wolniej zamiast szybciej, dokładniej zamiast ,atrakcyjniej”. Ten sam badacz zaproponował również trzy zasady zarządzania przetwarzaniem koniecznym ( $\mathrm{tj}$. podstawowym przetwarzaniem poznawczym koniecznym do tego, by mentalnie odzwierciedlać prezentowany materiał dydaktyczny) sugerujące potrzebę segmentacji materiały dydaktycznego (dostosowanie modułów do możliwości poznawczych uczących się), treningu wstępnego (związanego z zapewnieniem uczącym się podstawowych informacji o komponentach nauczania), modalności („wymaga prezentowania słów w formie dźwiękowej, dzięki czemu część przetwarzania koniecznego może zostać przerzucona z drogi wizualnej na werbalną, 25 ).

sensoryczność, poprzez zbytnie nagromadzenie informacji powoduje przekroczenie możliwości poznawczych ucznia. Jak opisuje to zjawisko Richard Meyer: „W przypadku złego zaprojektowania przekazu lub informacji zawierającej zbędny materiał uczeń musi angażować siły w bezcelowe przekształcanie, więc nie wystarczy już mu energii ani możliwości do podjęcia przetwarzania koniecznego lub twórczego, które są ważne w procesie uczenia się" (Meyer, 2014: 297).

${ }^{25}$ Mayer, 2013: 301. 
W ten właśnie sposób łącząc „,nowoczesne” z ,tradycyjnym” oraz korzystając z prostych zasad zarządzania cyfrowymi narzędziami najnowsze zdobycze technologii mają realną szansę nie tylko efektywnie funkcjonować w rzeczywistości edukacyjnej ale także jej nie zakłócać.

\section{Podsumowanie}

W niniejszym artykule wskazano na złożoność i niejednorodność zmieniającej się rzeczywistości, która wpływa na pojawianie się skrajnych opinii dotyczących przyszłości technologii oraz edukacji humanistycznej. Uznano jednak, że pomimo pojawiających się głosów o kryzysie współczesnej edukacji instytucjonalnej ma ona niezagrożoną pozycję we współczesnej przestrzeni społecznej. Ma także istotną do spełnienia misję w zakresie ochrony kultury, języka i wartości humanistycznych. Mimo wykazania trudnych relacji między technologią i edukacją oraz podkreślenia braku jednoznacznych wyników badań dotyczących istotnego wzrostu efektywności kształcenia z wykorzystaniem technologii informatycznych i mediów cyfrowych uznano, że powinny one mieć stałą reprezentację w procesie kształcenia. Uznano, że technologie informatyczne i media cyfrowe będą odgrywać coraz większą rolę w codziennym życiu ucznia oraz studenta (zwłaszcza w kontekście ich zakładanej kariery zawodowej). W związku z tym kształcenie nie może pomijać technologii jednak powinno one być wykorzystywane w powiązaniu z zakładanymi celami kształcenia oraz $w$ triadzie trzech najważniejszych $w$ tym kontekście kompetencji: komunikacyjnych, językowych oraz informatyczno/informacyjnych. Zwrócono uwagę, że nowoczesne kształcenie cyfrowe powinno respektować założenia psychologii poznawczej, konstruktywizmu z kognitywizmem i ustaleniami nowoczesnej neurodydakyki.

$$
* * *
$$

Podobnie jak nauczanie zawsze osadzone jest w konkretnym kontekście, tak i niniejszy artykuł również ma swój własny kontekst. Jest nim Jubileusz Profesora Stanisława Puppla oraz okrągła (bo 15) rocznica powstania Katedry Ekokomunikacji na Wydziale Neofilologii UAM w Poznaniu.

Gdybyśmy chcieli poszukać praktycznej realizacji zaprezentowanej w powyższym tekście pragmatycznej postawy wobec przemian cywilizacyjnych, zmian w edukacji oraz zdrowego podejścia do relacji między technologią a nauczaniem to bezdyskusyjnie odnajdziemy ją w filozofii Katedry Ekokomunikacji UAM oraz w postawie życiowej i naukowej prezentowanej przez Szanownego Jubilata. W tej postawie, bardzo mi bliskiej, uniwersytet (a raczej Universitas) wciąż jest elitarnym miejscem spotkania z drugim Człowiekiem, miejscem kontaktu z uporządkowaną 
i zdystansowaną do chaosu Wiedzą, jest w końcu przestrzenią, gdzie „pracownik naukowo-dydaktyczny" nadal jest przede wszystkim Badaczem, zaś dla swoich studentów Mistrzem. I oby nigdy się to nie zmieniło.

Z życzeniami wielu kolejnych lat aktywności naukowej, nowych pomysłów i nieustającego szczęścia do ludzi dedykuję powyższy tekst Profesorowi Stanisławowi Pupplowi.

\section{Bibliografia}

Anderson, J. i L. Rainie. 2012. „Millennials will benefit and suffer due to their hyperconnected lives”. Pew Research Center's Internet and American Life Project online: http://www.pewinternet.org/2012 /02 29/millennials-will-benefit-and-suffer-due-to-their-hyperconnected-lives/ [dostęp: 30.01.2017].

Arendt, H. 1994. Między czasem minionym a przysztym. Warszawa: Wyd. Aletheia.

Bednarek, J. 2006. Multimedia w ksztatceniu. Warszawa: Wydawnictwo naukowe PWN.

Biała Księga Kształcenia i Doskonalenia. Nauczanie i uczenie się. Na drodze do uczacego się społeczeństwa, Komisja Europejska. 1997. Warszawa: Wyższa Szkoła Pedagogiczna TWP.

Biedrzycki, K., Bobiński, W., Janus-Sitarz, A. i R. Przybylska (red.). 2014. Polonistyka dziś - ksztatcenie dla jutra. Tom 1-3. Kraków: Universitas.

Bush, V. 1945. „As we may think”. The Atlantic Monthly 176. 101-108.

Carr, N. 2010/2013. The shallows: what the Internet is doing to our brains/ Ptytki umyst. Jak Internet wptywa na nasz mózg. Gliwice: Helion.

Cuban, L. 1986. Teachers and machines: the classroom use of technology since 1920. New York: Teachers College Press.

Cuban, L. 2001. Oversold and underused. Computers in the classroom. Cambridge, MA.: Harvard University Press.

Czabanowska-Wróbel, A. 2014. „Czy naprawdę wiemy, gdzie jesteśmy? Uniwersyteckie kształcenie humanistyczne w kontekście socjologicznym”. W zbiorze: Biedrzycki, K., Bobiński, W., JanusSiarz, A. i R. Przybylska (red.). Polonistyka dziś - ksztatcenie dla jutra. Tom 1. Kraków: Universitas. 25-31.

Drucker, P. 1993/1999. Post-capitalist society/Społeczeństwo postkapitalistyczne. Warszawa: Wydawnictwo Naukowe PWN.

Drucker, P. 2002. Myśli przewodnie Druckera. Warszawa: Wyd. MT Biznes.

Dumont H., Instance, D. i F. Benevides (red.). 2010/2013. Educational research and innowavation. The nature of learning: using research to inspire practise/Istota uczenia się. Wykorzystanie wyników badań we praktyce. Warszawa: Wolters Kulwer Polska.

Huxley, A. 1932/1946. Brave new world. New York: Bantam Books.

Jenkins, H. 2006/2007. Convergence culture: where old and new media collide/Kultura konwergencji. Zderzenie starych i nowych mediów. Warszawa: Wydawnictwa Akademickie i Profesjonalne.

Koskiewiczowa, T. 2014. „Czy świat potrzebuje humanistów?”. W zbiorze: Biedrzycki, K., Bobiński, W., Janus-Siarz, A. i R. Przybylska (red.). Polonistyka dziś - ksztatcenie dla jutra. Tom 1. Kraków: Universitas. 32-42.

Kron, F.W. i A. Sofos (red.). 2003/2008. Mediendidaktik: Neue Medien in Lehr- und Lernprozessen/Dydaktyka mediów. Gdańsk: Gdańskie Wydawnictwo Psychologiczne.

Kwiek, M. 2015. Uniwersytet w dobie przemian. Warszawa: Wydawnictwo Naukowe PWN. 
Latoch-Zielińska, M., Morawska, I. i M. Potent-Ambroziewicz (red.). 2015. Edukacja a nowe media. Lublin: Wydawnictwo Uniwersytetu Marii Curie-Skłodowskiej.

Manovich, L. 2001/2006. The language of new medial Język nowych mediów. Warszawa: Wydawnictwa Akademickie i Profesjonalne.

Mayer, R. 2013. „Uczenie się z wykorzystaniem technologii”. W zbiorze: Dumont H., Instance, D. i F. Benevides (red ). 277-307.

Mayer, R. (red.). 2005. The Cambridge handbook of multimedia learning. New York: Cambridge University Press.

Mischke, J. (red.). 2005. Akademia on-line. Łódz: Wydawnictwo Wyższej Szkoły HumanistycznoEkonomicznej w Łodzi.

Naisbitt, J. 1997. Megatrendy. Poznań: Rebis.

Nelson, T. 1974. „From computer lib/ dream machine”. The New Media Reader. 331-338.

Nowak, A., Winkowska-Nowak, K. i L. Rycielska (red.). 2009. Szkoła w dobie Internetu. Warszawa: Wydawnictwo Naukowe PWN.

Postman, N. 1993/1995. Technopoly: the surrender of culture to technology/Technopol: triumf techniki nad kultura. Warszawa: Wydawnictwo Literackie MUZA.

Postman, N. 1995. The end of education: redefining the value of school. New York: Knopf.

Prensky, M. 2001. „Digital natives, digital immigrants”. On the Horizon 9. 1-6.

Puppel, S. 2008. „The Internet and the Web: a universal tool and a global resource for tayloring customized foreign language learning toolkits". W zbiorze: Myczko, K., Skowronek, B. i W. Zabrocki (red.). Tom jubileuszowy z okazji 70. urodzin Profesora Waldemara Pfeiffera. Poznań: Wydawnictwo Naukowe UAM.

Seattler, P. 1990. The evolution of American educational technology. Englewood Cliffs, NJ: Educational Technology.

Spitzer, M. 2002/2012. Lernen: Gehirnforschung und die Schule des Lebens/Jak uczy się mózg. Warszawa: Wydawnictwo Naukowe PWN.

Spitzer, M. 2012/2013. Digitale Demenz: Wie wir uns und unsere Kinder um den Verstand bringen/Cyfrowa demencja. W jaki sposób pozbawiamy rozumu siebie i swoje dzieci. Słupsk: Wyd. Dobra Literatura.

Spitzer, M. 2015/2016. Cyberkrank!: Wie das digitalisierte Leben unsere Gesundheit ruiniert jetzt kamfen Cyberchoroby. Jak cyfrowe życie rujnuje nasze zdrowie. Słupsk: Wyd. Dobra Literatura.

Steinbrink, B. 1993. Multimedia. U progu XXI wieku. Wrocław: Wyd. Robomatic.

Sweller, J. 1993. Instructional design in technical areas. Camberwell: ACER Press.

Toffler, A. 1997. Trzecia fala. Warszawa: PiW.

Trow, M. 2010. "Problems in transition from elite to mass higher education". W zbiorze: Burrage, M. (red.). Twentieth-century higher education. Elite to mass to universal. Baltimore: The Johns Hopkins University Press. 86-142.

Walat, A. 2007. „O konstrukcjonizmie i ośmiu zasadach skutecznego uczenia się według Seymoura Paperta". Meritum 4. 8.

Wobalis, M. 2011. „Multimedia i ich wpływ na edukację i uczenie się”. W zbiorze: Kwiatkowska-Ratajczak, M. (red.). Innowacje i metody. Tom 1. W kręgu teorii i praktyki. Podręcznik akademicki dydaktyki ksztatcenia polonistycznego. Poznań: Wydawnictwo Naukowe UAM. 237-248.

Wobalis, M. 2011. Multimedia w nauczaniu polonistycznym. Opis modelu hybrydowego e-podręcznika języka polskiego do liceum i badanie jego efektywności dydaktycznej w szkole. Poznań: Wydawnictwo „Poznańskie Studia Polonistyczne”.

Wobalis, M. 2016. „Kompetencje informatyczne studentów filologii polskiej w latach 2010-2016”. Polonistyka.Innowacje 4. 109-124. 